\title{
ANALISIS KUALITAS PRODUKSI APEL PADA DESA TUTUR KABUPATEN PASURUAN
}

\author{
Siti Nailul Alfiyah \\ Department of Management FEB UMM \\ Email : sitinailulalfiyah@gmail.com
}

\begin{abstract}
This research aims to know the quality of Apple production in Tutur Village Regency Pasuruan. By grouping into three groups, group with 0-5 apple farmer, group with 6-10 apple farmer, and group of more than 10 apple farmer. The population in this research and the entire manager and owner of the garden that is as much as 40 respondents. Data analysis used in this study is the range of the scale. Based on the results of the research and the discussion it can be concluded that: 0-5 apple farmer in which tenants are comprised of variable focusing on customers, continuous improvement, categorized well, while variable obsession to quality, involvement and empowerment of employees, categorized enough. 6-10 apple farmer grouping consisting of variable focusing on customers and variable obsession to quality categorized well, whereas continuous improvement, employee involvement and empowerment, categorized enough. Grouping more than 10 farmers apple farmer consisting of variable focusing on customers, variable obsession to quality, continuous improvement, employee involvement and empowerment, categorized either.
\end{abstract}

Keywords: quality, focusing on customers, obsession to quality, continuous improvement, employee involvement.

\section{PENDAHULUAN}

Semakin meningkatnya persaingan di dalam negeri diakibatkan oleh pesaing dari dalam dan luar negeri menyebabkan sektor pertanian dan perkebunan dituntut untuk membenahi sistem menejemennya. Hal ini dilakukan agar produk yang diproduksi mampu bertahan menghadapi persaingan global. Salah satu upaya dalam meningkatkannya tersebut yaitu dengan meningkatkan kualitas.

Kualitas sendiri menurut Goetsch dan Davis (1994) yaitu suatu kondisi dinamis yang berhubungan dengan produk, jasa, manusia, proses, dan lingkungan yang memenuhi atau melebihi harapan. Kualitas juga dinilai sering berubah sesuai dengan kondisi yang ada, yaitu kualitas dimasa depan tidak sama dengan kualitas saat ini.

Total Quality Management (TQM) sendiri bagian dari kualitas yang mengacu pada kualitas yang meliputi organisasi secara keseluruhan mulai dari pemasok sampai ke pelanggan. TQM menekankan pada komitmen oleh manajemen untuk memiliki terusmenerus menuju keunggulan dalam 
segala aspek barang dan jasa yang penting bagi pelanggan (Heizer dan Render, 2015). Jawa Timur sendiri memiliki kontribusi pada sektor perkebunan yang menjadi salah satu komoditas unggulan Jawa Timur. Salah satunya yaitu perkebunan apel yang berlokasi di Kecamatan Tutur Kabupaten Pasuruan yang merupakan salah satu penghasil apel terbesar di Jawa Timur. Hampir semua masyarakat di Kecamatan Tutur yang bekerja sebagai petani apel yang mengelola mulai dari proses pembibitan (input) hingga menjadi buah apel yang siap dipasarkan (output). Desa Tutur sendiri merupakan desa yang masyarakatnya paling banyak bekerja sebagai petani apel.

Data dari Badan Pusat Statistik atau BPS Jawa Timur (https://jatim.bps.go.id/statictable/20 18/02/08/891/produktivitas-sayurandan-buah-buahan-tahunan-di-jawatimur-kg-pohon-2008-2016.html) menyebutkan bahwa terjadi penurunan tingkat produktivitas buah apel pada Provinsi Jawa Timur tahun 2016.

Tabel 1. Tingkat Produktivitas Buah Apel Jawa Timur (Kg/Pohon)

\begin{tabular}{cccccccccc}
\hline Tahun & 2008 & 2009 & 2010 & 2011 & 2012 & 2013 & 2014 & 2015 & 2016 \\
\hline $\begin{array}{c}\mathrm{Kg} / \\
\text { Pohon }\end{array}$ & 0,07 & 0,11 & 61,09 & 65,95 & 71,13 & 83,92 & 107,57 & 101,26 & 44,36 \\
\hline
\end{tabular}

Pada data tabel diatas dapat dilihat bahwa terjadi penurunan jumlah produksi apel mulai dari tahun 2015. Apel yang dihasilkan pada tahun 2015 sebesar 101,26 $\mathrm{kg} /$ pohon, dan pada tahun 2016 mengalami penurunan lagi sebanyak $56,9 \mathrm{~kg} /$ pohon dari tahun 2015 menjadi 44,36 kg/pohon.

Menurut penuturan beberapa petani apel di Desa Tutur permasalahan yang dihadapi oleh petani yang menyebabkan terjadinya penurunan produksi yaitu, pengetahuan yang dimiliki oleh petani kurang memadai sehingga dalam proses pemupukannya tidak optimal mengakibatkan apel yang dihasilkan tidak semua baik dan juga kurang optimalnya pemeliharaan kebun menyebabkan kesuburan lahan kian menurun.

Kemudian kurangnya informasi untuk petani secara optimal dalam meningkatkan pengetahuan guna menunjang produksi apel yang semakin baik. Hal ini juga disebabkan oleh biaya produksi yang semakin mahal, modal petani tidak mencukupi untuk memelihara kebunnya secara optimal, dan menurunnya motivasi petani dalam memelihara kebun apelnya. Sehingga peneliti tertarik untuk meneliti bagaimana kualitas produksi apel pada desa Tutur Kabupaten Pasuruan.

\section{TINJAUAN PUSTAKA}

Penelitian yang mendukung penelitian ini yaitu penelitian yang dilakukan oleh Dewi Sinta K., Ma'mun Sarma, dan Aris Munandar (2017) berjudul Tingkat Penerapan Manajemen Mutu Pada Usaha IKM Chide Wrought Iron Design. Pada penelitian tersebut menggunakan rentang skala sebagai alat analisisnya dan menyimpulkan hasil penilaian rentang skala terhadap tingkat 
penerapan manajemen mutu yang dilakukan perusahaan berada pada rentang setuju, tetapi masih memerlukan perbaikan ke arah MMT. Sistem manajemen mutu pada IKM ChiDe Wrought Iron tidak membutuhkan terlalu banyak perbaikan, karena perusahaan tersebut sudah melaksanakan manajemen mutu yang melibatkan semua pihak, baik internal maupun eksternal.

Penelitian selanjutnya berjudul Analisis Pengelolaan Operasional dan Total Quality Management di CV. Star Digital Printing (Jesslyn Natalia, 2016). Dalam penelitian ini proses perencanaan operasional menyesuaikan dengan pesanan dan kapasitas mesin. Penjadwalan karyawan dan kontrol terhadap karyawan telah dilakukan dengan baik. Dalam organisasinya pemimpin perlu mengarahkan karyawan melalui briefing dan perlu diberitahukan kepada karyawan tentang struktur organisasi. Selain itu perlu adanya SOP tertulis agar karyawan mengetahui dan memahami job desk dengan lebih jelas.

Menurut Heyzer dan Render (2015) kualitas dapat didefinisikan dalam beberapa kategori yaitu berdasarkan pengguna (user based) menilai kualitas yang tinggi berarti kinerja yang lebih baik, fitur yang bagus dan peningkatan lainnya. Berdasarkan pada manufacturing (manufacturing based) menilai kualitas berarti sesuai dengan standar dan "membuatnya dengan benar pada kali pertama". Dan berdasarkan pada produk (product based) yaitu kualitas sebagai variabel yang dapat diukur.
Mutu atau kualitas (quality) memiliki definisi yang bervariasi dari yang konvensional sampaiyang lebih strategis. Definisi konvensional kualitas biasanya menggambarkan karakteristik langsung dari suatu produk, seperti performa (performance), keandalan (reliability), mudah dalam penggunaan, estetika (esthetics), dan sebagainya. Definisi strategis dari kualitas adalah segala sesuatu yang mampu memenuhi keinginan atau kebutuhan pelanggan (meeting the needs of customers). (Vincent Gaspersz, 2001).

Gasperz (2011) menjelaskan Total Quality Management yaitu suatu cara meningkatkan kinerja secara terus-menerus (Continously Performance Improvement) pada setiap level operasi atau proses dalam setiap area fungsional dari suatu organisasi menggunakan semua sumber daya manusia dan modal yang tersedia. Sedangkan pendapat dari Hansen dan Mowen (2009) mengemukakan bahwa Total Quality Management adalah suatu perbaikan berkelanjutan yang mana hal ini adalah sesuatu yang mendasar sifatnya bagi pengembangan proses manufaktur yang sempurna.

Fandy Tjiptono dan Diana (2001), berpendapat bahwa TQM merupakan pendekatan dalam meningkatkan tingkat produktivitas organisasi (kinerja kuantitatif), meningkatkan kualitas (menurunkan kesalahan dan tingkat kerusakan), meningkatkan evektifitas pada semua kegiatan, meningkatkan efisiensi (menurunkan sumberdaya melalui peningkatan produktivitas), dan mengerjakan segala sesuatu yang benar dengan cara yang tepat. 
Menurut Goetsch dan Davis (1994) yang disardur oleh M.N. Nasution (2010) menjelaskan tentang sepuluh unsur utama TQM pada (1) fokus pada pelanggan, pada pelanggan internal dan eksternal. Yang mana pelanggan internal berperan dalam menentukan kualitas tenaga keja, proses, dan lingkungan. Sedangkan pelanggan eksternal menetukan kualitas produk yang disampaikan kepada mereka. Dengan demikian dapat disimpulkan bahwa setiap produk yang dihasilkan perusahaan bertujuan untuk memenuhi kebutuhan pelanggan. Orientasi pada pelanggan tersebut akan membuat perusahaan untuk meningkatkan kinerjanya agar menghasilkan produk yang bermutu untuk memuaskan pelanggan. (2) obsesi terhadap kualitas, dengan ketentuan kualitas yang telah ditetapkan, organisasi harus terobsesi baik untuk memenuhi atau melebihi kualitas yang telah ditentukan.

Kualitas tersebut meliputi kualitas produk/jasa, tenaga kerja, proses dan lingkungan kerja dimana kualitas merupakan faktor penting untuk meningkatkan kinerja perusahaan dan karyawan serta dalam menarik konsumen/pelanggan. (3) pendekatan ilmiah, diperlukan terutama untuk mendesain pekerjaan dan dalam proses pengambilan keputusan dan pemecahan masalah yang berkaitan dengan pekerjaan yang didesain tersebut. Dengan demikian, data diperlukan dan dipergunakan dalam menyusun patok duga (benchmark), memantau prestasi, dan melaksanakan perbaikan. (4) komitmen jangka panjang, TQM merupakan suatu paradigma baru dalam melaksanakan bisnis. Untuk itu, dibutuhkan budaya perusahaan yang baru pula. Oleh karena itu, komitmen jangka panjang sangat penting guna mengadakan perubahan budaya agar penerapan TQM dapat berjalan dengan sukses.

(5) kerjasama tim (Teamwork), dalam organisasi yang dikelola secara tradisional seringkali diciptakan persaingan antar departemen yang ada dalam organisasi tersebut agar daya saingnya terdongkrak. Sementara itu, dalam organisasi yang menerapkan Total Quality Management, kerjasama tim, kemitraan, dan hubungan dijalin dan dibina, baik antar karyawan perusahaan maupun dengan pemasok, lembaga-lembaga pemerintah, dan masyarakat sekitarnya. (6) perbaikan sistem berkesinambungan. Setiap produk dan atau jasa dihasilkan dengan memanfaatkan proses-proses tertentu di dalam suatu sistem/ lingkungan. Oleh karena itu, sistem yang ada perlu diperbaiki secara terus-menerus agar kualitas yang dihasilkannya dapat makin meningkat. (7) pendidikan dan pelatihan, Dewasa ini masih terdapat perusahaan yang menutup mata terhadap pentingnya pendidikan dan pelatihan karyawan.

Kondisi seperti itu menyebabkan perusahaan yang bersangkutan tidak berkembang dan sulit bersaing dengan perusahaan lainnya, apalagi dalam era persaingan global. Sedangkan dalam organisasi yang menerapkan Total Quality Management, pendidikan dan pelatihan merupakan faktor yang fundamental. Setiap orang diharapkan dan didorong untuk terus belajar. Dengan belajar, setiap orang dalam perusahaan dapat 
meningkatkan keterampilan teknis dan keahlian profesionalnya. (8) kebebasan yang Terkendali, dalam Total Quality Management, keterlibatan dan pemberdayaan karyawan dalam pengambilan keputusan dan pemecahan masalah merupakan unsur yang sangat penting.

Hal ini dikarenakan unsur tersebut dapat meningkatkan 'rasa memiliki dan tanggung jawab karyawan terhadap keputusan yang telah dibuat. Meskipun demikian, kebebasan yang timbul karena keterlibatan dan pemberdayaan tersebut merupakan hasil dari pengendalian yang terencana dan terlaksana dengan baik. (9) Kesatuan tujuan, agar Total Quality Management dapat diterapkan dengan baik, maka perusahaan harus memiliki kesatuan tujuan. Dengan demikian, setiap usaha dapat diarahkan pada tujuan yang sama. Akan tetapi, kesatuan tujuan ini tidak berarti bahwa harus selalu ada persetujuan/ kesepakatan antara pihak manajemen dan karyawan, misalnya mengenai upah dan kondisi kerja. (10) adanya keterlibatan dan pemberdayaan karyawan, merupakan usaha untuk meningkatkan kemungkinan dihasilkannya keputusan yang baik, rencana yang baik, atau perbaikan yang lebih efektif, karena juga mencakup pandangan dan pemikiran dari pihak -pihak yang langsung berhubungan dengan situasi kerja serta meningkatkan 'rasa memiliki' dan tanggung jawab atas keputusan dengan melibatkan orang - orang yang harus melaksanakannya.

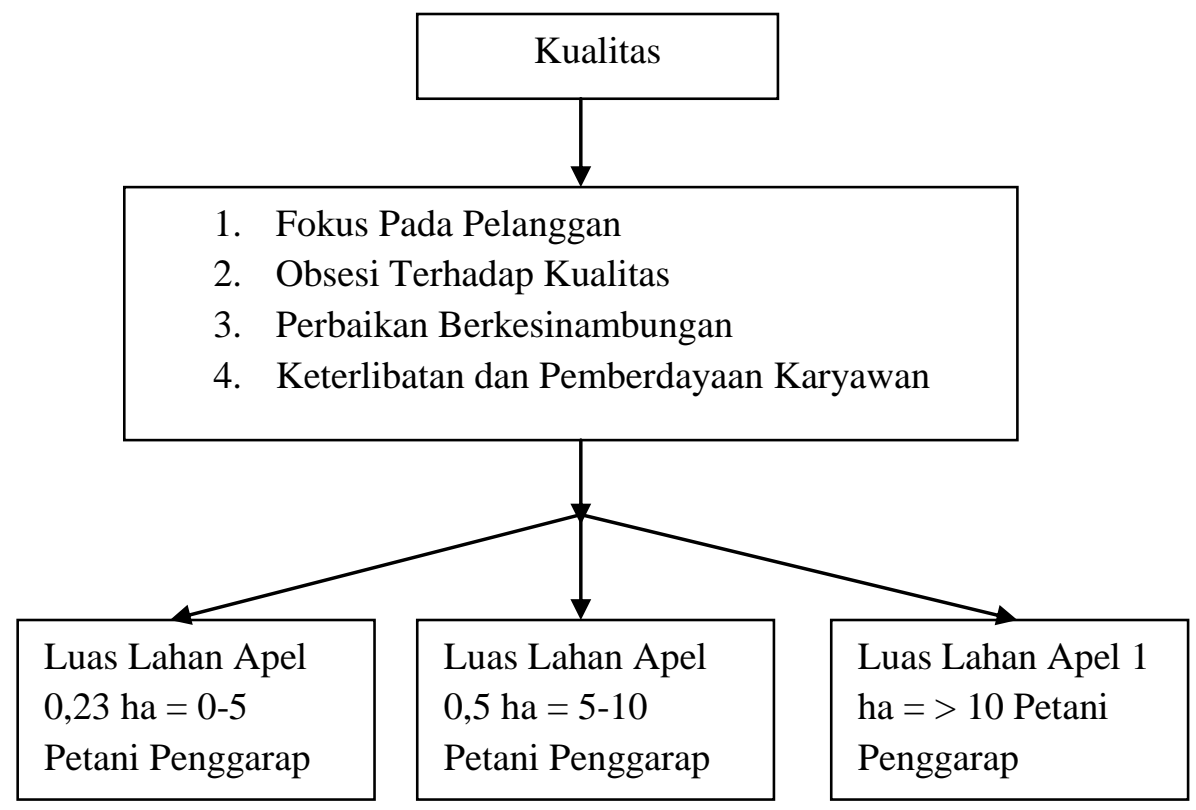

Gambar 1. Kerangka Pikir Penelitian

\section{METODE PENELITIAN}

Jenis penelitian ini yaitu penelitian diskriptif kuantitatif. Data yang dibutuhkan dalam penelitian ini yaitu data primer didapatkan langsung dari responden yaitu pemilik dan pengelola kebun apel melalui lembar kuisoner yang telah 
dibagikan. Teknik pengumpulan data yang dilakukan yaitu wawancara dan penyebaran kuisoner pada pemilik dan pengelola kebun apel.

Penelitian ini dilaksanakan di Desa Tutur Kabupaten Pasuruan. Popolusi dan sampel dalam penelitian ini yaitu 40 petani pemilik dan penggarap sesuai dengan jumlah petani yang ada. Metode analisis data yang dilakukan dalam penelitian ini yaitu menggunakan rentang skala yang sebelumnya diuji terlebih dahulu dengan uji validitas ( $\mathrm{r}$ hitung $>\mathrm{r}$ tabel) dan uji reabilitas (koefisien keandalan reliabilitas sebesar 0,60 atau lebih) untuk mengetahui apakah data yang diperoleh benar-benar dapat menjelaskan variabel dan $\mathrm{n}$ konsisten.

\section{HASIL DAN PEMBAHASAN}

Karakteristik responden dalam penelitian ini didapatkan hasil bahwa mayoritas reponden berada dalam rentang usia 51-60 dan dinilai sebagai usia berpengalaman dalam mengelola perkebunan apel yang berada di Desa Tutur Kecamatan Tutur Kabupaten Pasuruan.

Tabel 2. Karakteristik Responden Berdasarkan Usia

\begin{tabular}{ccc}
\hline $\begin{array}{c}\text { Rentang } \\
\text { Usia }\end{array}$ & Jumlah & Persentase \\
\hline $31-40$ & 4 & $10 \%$ \\
$41-50$ & 14 & $35 \%$ \\
$51-60$ & 20 & $50 \%$ \\
$61-70$ & 2 & $5 \%$ \\
\hline Total & 40 & $100 \%$ \\
\hline
\end{tabular}

Tabel 3. Karakteristik Responden Berdasarkan Jenis Kelamin

\begin{tabular}{lcc}
\hline $\begin{array}{c}\text { Jenis } \\
\text { Kelamin }\end{array}$ & Jumlah & Persentase \\
\hline Laki - Laki & 39 & $97,5 \%$ \\
Perempuan & 1 & $2,5 \%$ \\
\hline Total & 40 & $100 \%$ \\
\hline
\end{tabular}

Tabel 3 diatas menunjukan bahwa sebagian petani apel di Desa Tutur lebih banyak di dominasi oleh kelompok laki-laki. Keadaan ini dikarenakan banyak laki-laki sebagai kepala keluarga yang lebih banyak bekerja dan lebih mengetahui tentang bertanam apel daripada perempuan di desa Tutur.

Tabel 4. Karakteristik Responden Berdasarkan Pendidikan

\begin{tabular}{ccc}
\hline Pendidikan & Jumlah & Persentase \\
\hline SD & 3 & $7,5 \%$ \\
SMP & 11 & $27,5 \%$ \\
SMA/K & 17 & $42,5 \%$ \\
Diploma & 2 & $5 \%$ \\
S1 & 7 & $17,5 \%$ \\
Total & 40 & $100 \%$ \\
\hline
\end{tabular}

Tabel 4 menunjukkan latar belakang pendidikan pemilik dan maupun pengelola dalam mengelola kebun apel dinilai pemilik maupun pengelola mampu mengembangkan bisnis dan menunjang usaha bisnis apel sebagai wisata hingga dijual keluar kota dan toko-toko ritel.

Tabel 5. Karakteristik Responden

Berdasarkan Status Responden

\begin{tabular}{lcc}
\hline \multicolumn{1}{c}{ Status } & Jumlah & Persentase \\
\hline $\begin{array}{l}\text { Pengelola } \\
\text { Kebun Apel }\end{array}$ & 2 & $5 \%$ \\
$\begin{array}{l}\text { Pemilik dan } \\
\text { Pengelola }\end{array}$ & 38 & $95 \%$ \\
Kebun Apel & & \\
\hline \multicolumn{1}{c}{ Total } & 40 & $100 \%$ \\
\hline
\end{tabular}

Tabel 5 menunjukkan bahwa banyak petani apel adalah pemilik dan pengelola kebun apel, artinya rata-rata para petani pemilik kebun apel mampu dalam merawat dan mengelola kebun apelnya sendiri. Sedangkan status petani pengelola 
menunjukkan pemilik kebun apel sesungguhnya tidak ikut turun langsung dalam pengelolaannya, sehingga diserahkan kepada petani.

Tabel 6. Karakteristik Responden Berdasarkan Lama Usaha

\begin{tabular}{ccc}
\hline $\begin{array}{c}\text { Lama Usaha } \\
\text { Berdiri }\end{array}$ & Jumlah & Persentase \\
\hline $2-5 \mathrm{Th}$ & 1 & $2,5 \%$ \\
$5,1-10 \mathrm{Th}$ & 18 & $45 \%$ \\
$>10 \mathrm{Th}$ & 21 & $52,5 \%$ \\
\hline Total & 40 & $100 \%$ \\
\hline
\end{tabular}

Tabel 6 menunjukkan bahwa petani sebagai produsen apel yang paling banyak lebih dari 10 tahun dan membuktikan bahwa responden tersebut sudah terlatih dalam menjalankan usahanya. Hal tersebut dikarenakan karena petani telah paham dan mengerti dalam berkebun apel dengan pengalaman lebih dari 10 tahun.
Tabel 7. Karakteristik Responden Berdasarkan Jumlah Petani Penggarap

\begin{tabular}{ccc}
\hline Jumlah Petani & Jumlah & Persentase \\
\hline $0-5$ Orang & 12 & $32,5 \%$ \\
6 - 10 Orang & 11 & $27,5 \%$ \\
$>$ 10 Orang & 17 & $42,5 \%$ \\
\hline Total & 40 & $100 \%$
\end{tabular}

Tabel 7. menggambarkan seberapa besar kebun apel yang dikelola oleh responden. Jumlah petani lebih dari 10 memperlihatkan bahwa kebun yang di kelola mencapai 1,0 ha atau sekitar 1.0001.200 pohon. Selanjutnya 0-5 petani penggarap dengan jumlah 12 responden atau $32,5 \%$ menunjukan luas kebun apel sebesar 0,23 ha atau sekitar 400-500 pohon, dan 6-10 petani penggarap dengan jumlah 11 responden atau $27,5 \%$ menunjukan luas kebun apel sebesar 0,5 ha atau sekitar 700-850 pohon apel.

Tabel 8. Hasil Uji Validitas

\begin{tabular}{lcccc}
\hline \multicolumn{1}{c}{ Variabel } & Item & $r_{\text {hitung }}$ & $r_{\text {tabel }}$ & Keterangan \\
\hline \multirow{2}{*}{ Fokus Pada Pelanggan $\left(X_{1}\right)$} & $\mathrm{X}_{1.2}$ & 0,848 & 0,312 & Valid \\
& $\mathrm{X}_{1.2}$ & 0,868 & 0,312 & Valid \\
Obsesi Terhadap Kualitas $\left(X_{2}\right)$ & $\mathrm{X}_{2.1}$ & 0,906 & 0,312 & Valid \\
& $\mathrm{X}_{2.2}$ & 0,867 & 0,312 & Valid \\
Perbaikan & $\mathrm{X}_{2.3}$ & 0,830 & 0,312 & Valid \\
Berkesinambungan $\left(X_{3}\right)$ & $\mathrm{X}_{3.1}$ & 0,908 & 0,312 & Valid \\
Adanya Keterlibatan dan & $\mathrm{X}_{3.2}$ & 0,932 & 0,312 & Valid \\
Pemberdayaan Karyawan $\left(X_{4}\right)$ & $\mathrm{X}_{4.1}$ & 0,908 & 0,312 & Valid \\
\hline
\end{tabular}

Tabel 9 Hasil Uji Reliabilitas

\begin{tabular}{lll}
\hline Variabel & $\begin{array}{l}\text { Koefisien Alpha } \\
\text { Cronbach }\end{array}$ & Keterangan \\
\hline Fokus Pada Pelanggan $\left(X_{1}\right)$ & 0,641 & Reliabel \\
Obsesi Terhadap Kualitas $\left(X_{2}\right)$ & 0,811 & Reliabel \\
Perbaikan & 0,815 & Reliabel \\
Berkesinambungan $\left(X_{3}\right)$ & & Reliabel \\
Adanya Keterlibatan dan & 0,751 & \\
Pemberdayaan Karyawan $\left(X_{4}\right)$ & & \\
\hline
\end{tabular}


Berdasarkan Tabel 8, dapat diketahui bahwa seluruh item pernyataan didalam kuesioner mempunyai nilai $\mathrm{r}$ hitung $\geq \mathrm{r}$ tabel, sehingga dapat dikatakan bahwa seluruh item pertanyaan tersebut layak atau valid digunakan sebagai pengumpul data. Tabel 9. Memperlihatkan bahwa variabel dalam penelitian ini memiliki nilai koefisien Alpha Cronbach lebih besar dari 0,60 sehingga dapat disimpulkan bahwa instrumen yang digunakan dalam penelitian ini sudah reliabel. Hasil analisis rentang skala pada penelitian ini, dapat dibahas secara singkat berdasarkan rentang skala untuk kelompok dengan jumlah 0-5 petani penggarap. Variabel berfokus pada pelanggan dengan skor rata-rata yaitu 48 dikategorikan baik. Hal ini menunjukan bahwa petani penggarap melakukan fokus terhadap pelanggan dengan baik yaitu adanya hasil apel yang berukuran kecil dan sedang dengan jenis apel Anna, Manalagi, dan Merah. Selain itu petani apel juga memproitaskan pengepul apel sebagai distributor pertamanya.

Aspek obsesi terhadap kualitas dengan skor rata-rata rentang skala yang didapat yaitu 36,7 dikategorikan cukup. Hal ini menunjukan bahwa petani penggarap perlu melakukan peningkatan kualitas. Dari jawaban responden banyak petani yang belum mengoptimalkan atau mengikuti pelatihan dari Dinas Pertanian maupun memanfaatkan sarana diskusi kelompok tani apel Desa Tutur. Selain itu fokus petani dalam proses pembibitan, proses perawatan, dan proses panen dinilai cukup bermodalkan pengalaman yang ada.
Sedangkan dalam peningkatan kualitas produksi apel petani kurang memperhatikan apel sehingga kualitas apel yang dihasilkan banyak yang berukuran kecil.

Aspek perbaikan berkesinambungan dengan kor ratarata rentang skala yaitu 44,5 dikategorikan baik. Hal ini menunjukan bahwa petani penggarap melakukan perbaikan terus menerus dengan baik yaitu dengan melakukan perbaikan sistem irigrasi dan pemupukan. Kesigapan memperbaiki sistem tersebut mengakibatkan proses dalam produksi apel berjalan dengan lancar sehingga sedikit ditemukan apel yang tidak layak dijual maupun dikonsumsi.

Aspek keterlibatan dan pemberdayaan karyawan dengan skor rata-rata rentang skala yang didapat yaitu 34 dikategorikan cukup. Hal ini menunjukan bahwa petani penggarap belum sepenuhnya ikut andil dalam membuat keputusan bersama dan belum sepenuhnya bisa menyampaikan semua gagasangagasan mereka. Hal ini terjadi karena pemilik tidak sepenuhnya melibatkan petani penggarap dalam segala hal termasuk dalam berdiskusi untuk memecahkan masalah maupun evaluasi kerja petani penggarap.

Berdasarkan rentang skala untuk kelompok dengan jumlah 6-10 petani penggarap aspek berfokus pada pelanggan dengan skor rata-rata 39,5 dikategorikan baik. Hal ini menunjukan bahwa petani penggarap melakukan fokus terhadap pelanggan dengan baik yaitu adanya hasil apel yang berukuran kecil, sedang, dan besar dengan jenis apel Anna, Manalagi, dan Merah. Selain menjual apel pada pengepul yang merupakan 
distributor, petani apel sebagian juga mampu memasarkan apel pada ritelritel di Jawa Timur.

Aspek obsesi terhadap kualitas dengan skor rata-rata 37,7 dikategorikan baik. Hal ini menunjukan bahwa petani penggarap dinilai baik dalam menjaga kualitasnya. Dari jawaban responden sebagian petani belum mengoptimalkan pelatihan dari Dinas Pertanian sehingga perlu ditingkatkan kesadaran pentingnya pelatihan guna mendukung pengetahuan dalam berkebun apel. Selain itu fokus petani dalam proses pembibitan, proses perawatan, dan proses panen dinilai baik. Dilihat dari hasil apel yang telah dipanen menunjukan kualitas apel yang bervariasi ukuran dengan ukuran terbanyak yang dihasilkan yaitu berukuran sedang. Dan jenis apel yang dihasilkan bervariasi yaitu apel Anna, Manalagi, dan apel Merah.

$$
\text { Aspek }
$$

perbaikan

berkesinambungan dengan skor ratarata rentang skala yang didapatkan yaitu 36,5 dikategorikan cukup. Hal ini menunjukan bahwa petani penggarap melakukan perbaikan berkesinambungan dengan cukup baik yaitu dengan melakukan perbaikan sistem irigrasi dan pemupukan. Dengan luas lahan kurang lebih 0,5 ha membuat petani harus melalukan kesigapan dalam perbaikan sistem yang ada. Luas lahan tersebut mengakibatkan perbaikan sistem irigrasi terkadang membutuhkan waktu yang lama, namun petani apel dapat memperbaiki sistem sehingga tidak menyebabkan kerugian yang banyak. Demikian petani apel dinilai cukup dalam melakukan perbaikan berkesinambungan.

Aspek keterlibatan dan pemberdayaan karyawan dengan skor rata-rata rentang skala yang didapat yaitu 36 dikategorikan cukup. Hal ini menunjukan bahwa petani penggarap belum sepenuhnya ikut andil dalam membuat keputusan bersama dan belum sepenuhnya bisa menyampaikan semua gagasangagasan mereka. Hal ini terjadi karena pemilik tidak sepenuhnya melibatkan petani penggarap dalam segala hal termasuk dalam berdiskusi untuk memecahkan masalah maupun evaluasi kerja petani penggarap.

Berdasarkan rentang skala untuk kelompok dengan jumlah $>10$ petani penggarap pada aspek berfokus pada pelanggan dengan skor rata-rata 67 dikategorikan baik. Hal ini menunjukan bahwa petani penggarap melakukan fokus terhadap pelanggan dengan baik yaitu adanya hasil apel yang berukuran sedang dan besar dengan jenis apel Anna, Manalagi, dan Merah. Selain menjual apel pada pengepul, petani apel juga memasarkan apel pada ritel-ritel, dan membuka wisata petik apel guna menjaga loyalitas pelanggan terhadap apel yang dihasilkan.

Aspek obsesi terhadap kualitas dengan skor rata-rata rentang skala yang didapat yaitu 62,7 dikategorikan baik. Hal ini menunjukan bahwa petani penggarap dinilai baik dalam menjaga kualitasnya. Sebagian petani belum mengoptimalkan pelatihan dari Dinas Pertanian sehingga perlu ditingkatkan kesadaran pentingnya pelatihan guna mendukung pengetahuan dalam berkebun apel. 
Selain itu fokus petani dalam proses pembibitan, proses perawatan, dan proses panen dinilai baik. Dilihat dari hasil apel yang telah dipanen menunjukan kualitas apel yang bervariasi ukuran dengan ukuran terbanyak yang dihasilkan yaitu berukuran sedang dan besar. Dan jenis apel yang dihasilkan bervariasi yaitu apel Anna, Manalagi, dan apel Merah. Kegiatan bisnis lain yang dilakukan yaitu dengan membuka wisata petik apel yang banyak diminati oleh para konsumen. Untuk meningkatkan kualitas dalam wisata ini, konsumen diperbolehkan untuk memilih kualitas apel baik dari variasi jenis dan ukuran apel.

Aspek perbaikan secara berkesinambungandengan skor ratarata 66,5 dikategorikan baik. Hal ini menunjukan bahwa petani penggarap melakukan perbaikan dengan baik yaitu melakukan perbaikan sistem irigrasi dan pemupukan. Para petani penggarap didorong untuk selalu tepat dan cepat dalam melakukan perbaikan sistem tersebut, hal ini juga didorong oleh bisnis wisata petik apel dimana konsumen dapat melihat secara langsung kebun dan proses yang terjadi. Dimana petani penggarap dinilai mampu melakukannya dengan baik melihat tidak adanya masalah pada sistem irigrasi dan pemupukan sehingga konsumen yang datang dapat menikmati wisata petik apel tanpa adanya kendala.

Aspek keterlibatan dan pemberdayaan karyawan dengan skor 59 dikategorikan baik. Hal ini menunjukan bahwa petani penggarap dapat menyampaikan gagasangagasan tentang solusi masalah dan evaluasi kerja.
Keterbukaan pemilik dalam mendengarkan gagasan-gagasan tersebut berdasarkan pemahaman bahwa petani penggarap lebih memahami kondisi lapangan yang ada. Hal ini dikarenakan petani penggarap selalu melakukan aktivitas berkebun sehingga mengetahui semua keadaan dikebun. Selain itu tidak semua pemilik kebun membuat keputusan-keputusan mengenai masalah yang ada bermasa petani penggarap. Tidak banyaknya keterlibatan petani penggarap dalam membuat keputusan bersama dengan pemilik dinilai cukup, yang berarti pemilik memiliki wewenang yang hanya dilakukan oleh pemilik kebun.

\section{SIMPULAN}

Berdasarkan hasil penelitian yang telah dilakukan dapat disimpulkan bahwa pada pengelompokkan 0-5 petani apel penggarap yang terdiri dari variabel berfokus pada pelanggan, perbaikan berkesinambungan, dikategorikan baik, sedangkan variabel obsesi terhadap kualitas, keterlibatan dan pemberdayaan karyawan, dikategorikan cukup.

Pada pengelompokkan 6-10 petani apel penggarap yang terdiri dari variabel berfokus pada pelanggan dan variabel obsesi terhadap kualitas dikategorikan baik, sedangkan perbaikan berkesinambungan, keterlibatan dan pemberdayaan karyawan, dikategorikan cukup. Pada pengelompokkan lebih dari 10 petani apel penggarap yang terdiri dari variabel berfokus pada pelanggan, variabel obsesi terhadap kualitas, perbaikan berkesinambungan, 
keterlibatan dan pemberdayaan karyawan, dikategorikan baik.

\section{DAFTAR PUSTAKA}

BPS Jatim. 2017. Produktivitas Sayuran dan Buah-Buahan Tahunan di Jawa Timur kg Pohon 2008-2016 di (di akses pada 27 Desember 2017)

Chairany, Nurul dan Wahyuni Lestari. 2011. Pengaruh Total Quality Management Terhadap Kinerja Perusahaan Melalui Kepemimpinan dan Perilaku Produktif Karyawan. Makassar.

Gasperz, Vincent. 2002. Lean Six Sigma. Jakarta: PT. Gramedia Pustaka Utama.

Ghozali, Imam. 2016. Aplikasi Analisis Multivariete IBM SPSS 23. Semarang: Badan Penerbit Universitas Diponegoro.

Hansen \& Mowen. 2001. Manajemen Biaya Akuntansi dan Pengendalian. Jakarta: Salemba Empat.

Heizer, Jay dan Berry Render. 2015. Manajemen Operasi

Manajemen Keberlangsungan Rantai Pasokan. Edisi 11. Jakarta: Salemba Empat.

Indrianto, Nur, dan Bambang Supomo. 2009. Metodologi Penelitian Bisnis untuk Akuntansi dan Manajemen. Yogyakarta : BPFE Yogyakarta.

Munizu, Musran. 2010. Praktik Total Quality Management (TQM) Dan Pengaruhnya Terhadap Kinerja Karyawan (PT. Telkom Tbk. Cabang Makassar)

Natalia, Jesslyn. 2016. Analisis Pengelolaan Operasional dan Total Quality Management di
CV. Surabaya: Agora Vol. 4 No.2.

Nasution. 2010. Manajemen Mutu Terpadu - Total Quality Management. Bogor: Ghalia Indonesia.

Sanusi, Anwar. Metodologi Penelitian Bisnis Disertai Contoh Proposal Penelitian Bidang Ilmu Ekonomi dan Manajemen. Jakarta Selatan: Salemba Empat.

Sinta, Dewi. K, Ma'mun Sarma, dan Aris Munandar. 2017. Tingkat Penerapan Manajemen Mutu Pada Usaha IKM Chide Wrought Iron Design. Bogor: Vol. 7 No.2.

Sugiyono. 2010. Metode Penelitian Bisnis. Jakarta: Salemba Empat.

Tjiptono, Fandy, dan Anastasia Diana. 2001. Total Quality Management. Yogyakarta: ANDI.

Widjaya, Hannes Oey, dan Ian Nurpatria Suryawan. 2014. Pengaruh Total Quality Management (TQM) dan Quality Management Information (QMI) Terhadap Kinerja Perusahaan. Jakarta.

Yulima, Alisa Siregar dan Samsir. 2017. Pengaruh Implementasi

Total Quality Management (TQM) Terhadap Pencapaian Kinerja Perusahaan TNTEXPRESS INDONESIA. Riau: Vol. IX. No.3.

Zikmund, G. W dan Babin. B. J. (2013). Menjelajahi Riset Pemasaran, Exploring Marketing Research. Jakarta: Penerbit Salemba Empat. 